\title{
The trial of Giorgio Moreto before the Inquisition in Venice, 1589
}

\author{
Brian Pullan
}

Since the 1960s, historians of the great continental inquisitions of Rome, Spain and Portugal have divided into schools and put their documents to different uses. ${ }^{1}$ Some of them incline to the belief that court records are efficient only at performing the task of showing how courts proceeded, and that they can afford only a sectional view, taken from a peculiar angle, of the prisoners and witnesses who came before the courts to undergo interrogation. Historians who hold this opinion have therefore concentrated on the structure and functions of the inquisitions themselves; on the mentality, aims and methods of their judges, officials and supporters; on the political struggles and personal rivalries that arose within the institutions; and on the relationship between inquisitions and diocesan and lay authorities in the states which accommodated them.

Other scholars, quite the other way, have turned to the prisoners rather than the judicial panels, and have looked to the trial records to provide a key to the mind and conduct of independent thinkers and rebels against ecclesiastical orthodoxy. Some have used the transcripts to examine systematic heresies formally condemned by papal bulls or conciliar pronouncements. Some have explored the ways in which inquisitions advanced or discouraged the process by which popular magic began to be perceived as diabolical witchcraft and prosecuted as apostasy from the Christian faith. Several writers, in search of the typical rather than the spectacular, have examined the routine cases which accounted for the bulk of the proceedings conducted by the Spanish and Roman Inquisitions. They have shown how, after the first few decades of the inquisitions' existence, when the Spanish Inquisition was no longer pursuing judaisers or the Roman Inquisition 'Lutherans' and Anabaptists, the judges' concern was mostly with lesser offences: how they pursued and corrected speeches or acts which amounted, not to fully fledged heresies, but merely to 'heretical propositions', to abuses of sacraments, to displays of 'scandalous' ignorance, to superstitious rituals rather than truly diabolical practices. 
Certain indefatigable researchers have proved themselves as 'historians of great numbers', undaunted by the prospect of analysing statistically the 44,000 cases which were examined by the Spanish Inquisition between the midsixteenth and the early eighteenth centuries and described in the relaciones de causas drawn up by the inquisitors and their assistants. ${ }^{2}$ Some, by nature project managers, have organised collective enterprises designed to compile more accurate and consistent inventories of the proceedings conducted by the many local tribunals of the Roman Inquisition in Italy. Their ambition is to make international comparisons and to plot the great trends in the institution's history, by identifying changes in the concerns of judges and prosecutors. ${ }^{3}$ Other scholars, the miniaturists of the discipline, fascinated by the peculiar qualities of particular cases, have striven to "see a world in a grain of sand', to uncover the hidden culture of obscure people by paying close attention to particular trials or to groups of trials which illustrate a theme. Trial transcripts have enabled them to write compelling studies of ordinaryextraordinary folk in the firm belief that these have as much right to biography as do people of status. Individualists, persons of modest social rank but heterodox opinions and eccentric behaviour, emerge vividly from the records if the inquisitors allow them to speak freely, as they give the floor to Domenico Scandella, the Friulian miller, or ask for written memoirs, as they do of Cecilia Ferrazzi, the pretended saint of seventeenth-century Venice. ${ }^{4}$

This chapter has the modest aim of illustrating the day-to-day workings of one tribunal, in the hope that readers will draw their own conclusions about the judges, the prisoner and the society in which they were placed. It will present in English translation the record of the trial of an obscure person who was arrested in April 1589 by the Inquisition (otherwise the Holy Office) in Venice. The transcript will perhaps throw light on the procedures and concerns of members of the court. It exemplifies the kind of story that inquisition records can tell about the way of life of people in casual employment, who lived by their wits rather than their skills as craftsmen: about the manners and customs of those who generally left no documentary traces apart from bald statements about their births, marriages and deaths in parish registers and necrologies.

The tribunal which inquired into the misconduct of Giorgio Moreto, 'Swarthy George', was one of some forty Italian branches of the Roman Inquisition, responsible to the Holy Office created in 1542 and the Congregation of the Index of 1571. The ecclesiastical judges of the Inquisition functioned with the collaboration, sometimes grudgingly and sometimes enthusiastically given, of the lay authorities in the states and cities which housed their tribunals. ${ }^{5}$ Giorgio was a ribald Venetian sailor, ordinary rather than ordinaryextraordinary, who attracted attention by creating scandal and ignoring the barriers which the Catholic Church and the Venetian State were seeking to maintain between Christians and Jews. Perhaps he was desperate for entertainment during Lent, the Christian season of intensified self-denial, or perhaps it 
was a natural sociability which drew him to the ghetto. He was not an isolated figure. Several Venetian youths shared his taste for unleavened bread and his pleasure in wearing a Jewish hat for a joke, although they did not stand trial with him. Giorgio's was one of seventy-five cases involving Jews and judaising, some with several defendants, which are known to have come before this tribunal in the second half of the sixteenth century. In one respect it was unusual. Most charges of judaising were levelled at baptised Christians of Jewish stock, many of whom had once been practising Jews themselves, and were now suspected of betraying their baptism by returning to or taking up the law of the Jews. Giorgio Moreto, however, apparently had no Jewish blood. He was a Venetian who hailed from the parish of the Madonna dell' Orto, in the district of Cannaregio, close to the ghetto. His crime was to haunt the Jewish quarter, particularly at night, in such a manner as to arouse suspicion that he was flirting with Judaism, and enjoying the company of Jews if not sharing their beliefs.

Giorgio's trial was briskly and decisively conducted. It involved the elements of an inquisition processo, without any frills - a denunciation; an inquiry or processo informativo based on information provided by the author of the denunciation, and directed not by police officers but by judges, who took sworn testimony by word of mouth and had it recorded, seemingly verbatim, by the court notary; arraignment and examination of the prisoner; a verdict and sentence. The judges acted both as examining magistrates and as the magistrates who pronounced judgment and sentence. Certain procedures, less vital to the make-up of a trial, were absent. The court did not draw up a written indictment. Nor did it formally invite the prisoner to make his defences, though under interrogation he put his own side of the case. No advocates were appointed for the prosecution or the defence. No formal abjuration was required of Giorgio and no spiritual penance was imposed upon him. All these things might well have been done in a more complicated process, on which - had there been any question of using torture or imposing a death sentence - judges in Venice would probably have sought advice from Rome.

In the absence of a formal indictment, it was not entirely clear what the charges were, or which the judges took most seriously. Apostasy, turning Jew in order to marry a Jewish sweetheart, was the gravest crime contemplated, but it was not the offence which eventually earned the culprit a sentence of harsh imprisonment. Several lesser crimes were mentioned and probably regarded as more susceptible of proof - breaking the Church's dietary laws, uttering heretical blasphemies, and disobeying the Inquisition itself by defying its injunction to stay away from the ghetto. Rejection of the Church's authority was an important component of heresy, though Giorgio, however disrespectful in his behaviour, never uttered any profound intellectual statements or devised any outlandish theories.

Presented here is a translation made from the monumental edition, by Pier Cesare Ioly Zorattini of the University of Udine, of all surviving trials of Jews 
and judaisers conducted by the Inquisition in Venice between 1548 and $1734{ }^{6}$ The court record has been fully rendered save that the translation does not repeat all the standard formulae used at the start and finish of each witness's testimony. They differ little from those employed with regard to the first Jewish witness examined (Jacob, son of David) and the first Christian witness (Alessandro, son of Innocenzo). The translation gives only the final version of the text drawn up by the court notary, and does not include the words he crossed out, either to correct his own errors or to introduce emendations requested by witnesses. The endnotes refer to one or two, but not all, of the marginal notes made by somebody going through the text and highlighting incriminating statements, perhaps with a view to drawing up a list of charges or of points on which the suspect was to be interrogated. Most of these notes merely state the obvious by repeating phrases used in the record, but occasionally they help to clarify obscure issues. Very likely, the texts which survive in the state archives, as this one does, are transcripts supplied to the Venetian noblemen who attended the court. They purport to give a complete account of the Inquisition's proceedings. However, the dialogue they record may not have been wholly spontaneous and some unrecorded events may have occurred off stage, for it is known that inquisitors sometimes approached witnesses beforehand or coached prisoners in the art of showing repentance. ${ }^{7}$

In fact, if not in canon law, the court which judged Giorgio Moreto was a mixed tribunal composed of clerical and lay members. Only clerics could pronounce sentences and only laymen could enforce them and enable the Inquisition to impose anything other than spiritual penances. In Venice, as in Genoa, or Savoy, or Ferrara, or Florence, the Holy Office could not make itself sufficiently feared without the magistrate's support. ${ }^{8}$ The constitution of the Venetian Inquisition was intended to bind together three authorities which shared an interest in the suppression of heresy and to enable them to act in unison, even though the possibility of jurisdictional conflict and mutual jealousy was latent in their relationship. Papal authority was represented firstly by the nuncio, who was not merely a diplomat but also a legate endowed with the powers of an inquisitorial judge, and secondly by the Dominican inquisitor, whose authority was delegated to him by apostolic brief. The 'ordinary', as distinct from delegated, authority of the patriarch of Venice was important to the tribunal, although it had not always been essential. In the words of the canonist Francisco Peña, writing in the late 1570s, 'There are two kinds of judges in matters of faith, the first being ordinaries, such as the supreme pontiff of Rome and the bishops of the various places, who receive power and jurisdiction over heretics by divine right when they are ordained or consecrated.' As the record of this trial shows, the patriarch usually delegated the task of hearing routine cases to his vicar, even as the nuncio entrusted some of his own responsibility to an assistant known as an auditor. Since the early fourteenth century, canon law had enjoined the ordinary and the inquisitor to act together when imprisoning a suspect, authorising torture or 
pronouncing sentence. They had not always done so in sixteenth-century Venice and, on occasion, the patriarch and his vicar-general had proved to be more aggressive than the inquisitor himself. ${ }^{9}$

Formal sessions of the tribunal were attended by at least one of the three senior Venetian magistrates known as the Tre Savii sopra l'Eresia, who acted as the eyes and ears of the Venetian State if not as its mouthpiece. They represented the Republic's legitimate interest in the pursuit of heresy. In Venice, as in most states and societies, heresy was associated with disorder and subversion, especially if the suspected heretics were Venetians, Venetian subjects, or other Italians. Venetian authorities showed less enthusiasm for pursuing Germans, Flemings or Frenchmen denounced for heresy while visiting or sojourning in Venice. Baptised Jews from Spain or Portugal who came to Venice as approved Jewish traders received guarantees against prosecution for heresy in and after the year of Giorgio's trial, $1589 .{ }^{10}$ As a native Venetian, Giorgio himself could plead no privilege and it could be said that his bad behaviour violated the laws of the State as much as those of the Church, for the Venetian Senate had created the Venetian ghetto and Venetian magistrates regulated it.

The Tre Savii existed both to spur the Inquisition on and to prevent it from acting against the State's commercial or political interests or trespassing on its jurisdiction. In Italy generally, complaints that the Inquisition was tepid and ineffective were as common as charges that it was breaking its bounds. ${ }^{11}$ Fierce controversy had arisen, especially between the Republic and Pope Julius III in 1550-1, over the precise role of lay judges in tribunals of the inquisition. Were they to be fully-fledged inquisitors themselves, or mere collateral judges and consultants, or simply coadjutors who supplied the force of the secular arm when called upon to do so? The State would have had them be judges; the pope threatened excommunication for laymen who infringed the jurisdiction of the Church. ${ }^{12}$

It seems clear that in 1589 the Savii were, as they had always been, more than mere executors of clerical decisions; they almost certainly took part in deliberations of the court, although in the past the State had been anxious that their interventions should not be recorded. ${ }^{13}$ Appointments to their positions were generally, until the mid-1590s, of a conciliatory nature, since most of the Savii were pious, elderly men unlikely to pick unnecessary quarrels with their ecclesiastical colleagues. They had almost invariably served as members of the Council of Ten, Venice's permanent committee of public safety; indeed, in the course of at least one trial, they had been said to represent the Ten in the Inquisition. ${ }^{14}$ Of the laymen who attended the Moreto trial, Giovanni Battista Querini, seventy-nine years of age, was serving his sixth term as a Savio; Andrea Bernardo, aged seventy-one and a former governor of Padua, his third term; and Federico Contarini, a new recruit, was a mere baby of fiftyone. He had risen with unnatural speed through Venice's gerontocratic political system because he had been able, in 1571, to purchase an honourable 
office, that of procurator (i.e. advocate or protector) of the church of St Mark's. This had given him access at an early age to the Ten and its attached committee, the Zonta. His pro-papal zeal and enthusiasm for the Jesuits were said to be so strong that, had the full extent of his Roman sympathies become known, his reputation in Venice would probably have been ruined. ${ }^{15} \mathrm{He}$ was hardly the man to restrain the Inquisition from acting against the irreverent and disorderly Moreto.

It was the task of the Inquisition to pursue heresy, even in its inchoate forms, and even where it seemed to arise out of ignorance or frivolity rather than from a resolution to defy the Church and question its teachings. Should people allegedly speak, act, or neglect their religious duties in such a way as to give rise to suspicion of heresy, the court could justifiably call on them to prove their faith and to confess, acknowledge and repent of errors. In Venice the Inquisition had no business with religious offences such as improperly entering convents or simple blasphemy, which, since they raised no subtle theological issues, could properly be dealt with by lay magistrates. ${ }^{16}$ It seems likely that Giorgio Moreto first fell into the hands of a Venetian police magistracy which suspected him of disorderly conduct and breaking the state's rules concerning the ghetto, but handed him over to the Inquisition when it became clear that his behaviour also bordered on the heretical because he was violating Lent and courting a Jewish girl.

Since the Savii sopra l'Eresia were active members of the court, the Inquisition was calling on representatives of what appeared to be very different legal systems, one based on professional and the other on amateur judges. The inquisitor and some of his colleagues were trained in theology or canon law or both these disciplines, and could read procedural manuals designed to take them through every step of the trial. ${ }^{17}$ On the other hand, Venice's republican political system was based on a brisk rotation of offices among members of a legally defined ruling order, a hereditary, untitled, urban nobility often called a patriciate. No distinction was made between judicial posts and fiscal or administrative offices, and no professional qualifications were required in order to fill any of them. As judges Venetian noblemen were expected to pay attention to equity and to exercise discretion and common sense in passing sentences. Venetians, jealous of their sovereignty, were well known for their refusal formally to acknowledge Roman and canon law, which they were believed to dismiss as unacceptable symbols of papal and imperial dominion. Many inquisition cases, however, involved straightforward questions of fact as much as theological issues, and the Moreto case was one of these, though it also raised questions about the intentions which lay behind the words and deeds attributed to the prisoner. The lay members of the court would have had something to contribute to the case's resolution, which dispensed entirely with spiritual ceremonies and penalties. ${ }^{18}$

The scene of Giorgio's crimes was the Venetian ghetto. This had originated in a disused copper foundry, on a site which had happened to be available in 
1516 when the voices of preachers, inveighing against intimacy between Christians and Jews, had become so strident that the government was disposed to pay them heed. Ghettoisation made it possible for Jews to live in Venice but not be of it, in a crowded enclave which was to some degree selfgoverning. In 1589 the ghetto consisted of two districts, the large Ghetto Nuovo originally intended for the so-called 'Germanic' Jews (many of whom were really Italians) and the small Ghetto Vecchio. Theoretically at least, the Ghetto Vecchio, which had been enclosed and reserved for Jewish occupation in 1541, was for 'Levantine' Jews who were, or had been, or could claim to be, subjects of the Ottoman Empire. ${ }^{19}$

Venice agreed to the presence of the Jews, partly because they served the economy by performing specialised functions, as Germanic and Italian Jews provided pawn offices and Spanish and Portuguese Jews promoted trade with the Levant; partly because they gave employment to Christians and consumed their products; and partly, too, because they were potential converts to Christianity. Since the mid-sixteenth century the city had maintained a house of converts, the Pia Casa dei Catecumeni, in which a small number of Jews and Muslims who had professed interest in turning to Christianity were instructed in the essentials of the Catholic faith. It was often argued that unless Jews lived in some place close to Christian society, they would never change their ways and beliefs. But in the view of authority, both ecclesiastical and lay, it was vital to maintain a hierarchical relationship between Christian and Jew, to demonstrate the superiority of Catholic Christianity to Judaism. It ought to be unthinkable that Christians should contemplate turning to Judaism, and it was scandalous that Giorgio Moreto should boast that he had thought of doing so. Proximity must not lead to intimacy, or business dealings to social relations: Christians were not to mingle with Jews on equal terms, to sit at their tables, to sleep under their roofs, or to share their beds. Levantine Jews bore turbans, but others were generally obliged to wear yellow or red hats, intended to forestall familiarity by contrasting garishly with the black hats of the Christian laity. As the trial record shows, frivolous disrespect for this badge of religious allegiance contributed to Giorgio Moreto's downfall. ${ }^{20}$

Separation between Christians and Jews was not intended to be total. The day was for business transactions; crowds of Christian customers flowed into the ghetto, bent on pledging or redeeming at the pawn offices, or on making purchases or sales at the second-hand shops. Giorgio Moreto described himself as doing 'a bit of brokering'. Indeed, the economic activities of Jews were liable, in Venice and other cities, to generate middlemen who dealt on behalf of clients with pawnbrokers and second-hand dealers, supervised and recorded transactions, and used their know-how to bring buyers and sellers together. In the late sixteenth century there were at least sixteen officially recognised brokers in the Venetian ghetto (twelve Christians and four Jews), and they were evidently concerned both with the second-hand trade conducted by the Germanic Jews and with the transactions of Levantine Jewish merchants. ${ }^{21}$ 
Three Christian brokers were summoned to give evidence in the Moreto case. It is unlikely that Giorgio himself, scraping a living by his wits, had any official status or paid the government's brokerage tax. But his trade gave him reason to be on the streets by day.

Giorgio was on much shakier ground when he ventured into houses by night. A curfew was imposed on Jews, from an hour or two after sundown, and enforced by the warders on duty at the gate. In March 1589 a decree of the magistrates in charge of the ghetto permitted Christians to remain in the place, at least in winter, until the fourth hour of the night, but only if they were performing recognised services for the Jews. ${ }^{22}$ Giorgio Moreto's enthusiastic participation in Jewish festivities would scarcely have met with official approval. Like the brokers, the warders on the ghetto gate were expected to be reliable and well-informed witnesses to occurrences in the Jewish quarter, and two of them were summoned by the Inquisition to testify in Moreto's case. One was the elderly Domenico Spadini, called 'the Gobbo', otherwise 'the hunchback'; the other was his son, Antonio, whom Giorgio accused of bearing false witness against him. Did Shakespeare get to hear of them, transform them into Lancelot and his gravel-blind father, 'Old Gobbo', and include through them an oblique reference to the ghetto in The Merchant of Venice? The story of Giorgio and his Jewish girl, Rachel, reads a little like a plebeian version of the tale of Lorenzo and Jessica, but without a happy ending. However, two of the main protagonists of Giorgio's story - Rachel and her father, Isaac the Deaf, - are tantalisingly absent from the list of witnesses examined by the Inquisition. ${ }^{23}$

By definition trials are concerned with improper behaviour and tell us about those alleged to have overstepped a mark. However, by studying deviance one comes to know what was considered correct, or at least what was expected by the authorities represented by the judges. Giorgio's offence was to challenge, perhaps unthinkingly, the orderly scheme which authorities, both clerical and lay, were seeking to impose upon Venice as upon other Catholic cities. Since all human beings were sinners, good and evil, fidelity and infidelity, chastity and fornication could all have their places in a Christian society. Indeed, institutionalised 'lesser evils' such as licensed prostitution and usurious moneylending could be justified on the grounds that they were practised by outcasts in such a way as to prevent them from corrupting respectable Christians. But right order had to be expressed visibly by reserving spaces for particular purposes and making attempts to separate good physically from evil, purity from impurity, the sacred from the profane. This end had to be achieved not only by means of the ghetto, but also through such measures as the separation of prostitutes' dwellings from sacred places and the ban on whores visiting churches at certain times; the protection of nunneries from violation; the removal of beggars from streets and churches and their consignment to the hospital of the Mendicanti, established in the $1590 \mathrm{~s}^{24}$ It seemed shocking to Giorgio's delator that he should mix up things that ought 
to be kept apart - not only that he should confuse Carnival and Lent, but also that, having scourged himself one day in honour of Christ's passion, he should venture the next day into the ghetto, the territory of Christ's enemies. No doubt the Roman Inquisition bore cases like his in mind when it decreed in 1598 that 'Christians attending Jewish circumcisions, accepting breakfasts [ientacula] or unleavened bread, serving in the houses of Jews, conversing with them in a familiar vein, or discussing matters of faith with them shall be punished, together with those very Jews, by the Holy Office. ${ }^{25}$

Up to a point Giorgio's conduct was ambiguous: his presence at Jewish festivities could conceivably be explained as part of a devious scheme to woo a Jewish girl and, by converting her, to win a soul for Christ. Even so, he had not informed or involved the officials of Venice's house of converts, the Pia Casa dei Catecumeni, and by failing to do so he was taking a grave risk. In the end, when he ignored the Holy Office's injunction to avoid the ghetto, there could be no doubt of his disobedience, whether drunk at the time or not, to authority and its explicit commands.

\section{The Record of Proceedings Against Giorgio Moreto}

Thursday 6 April 1589

Against Giorgio, called Moreto, otherwise the mariner. Presented by Don Jacopo, son of Pietro Malosso, deputy constable of the Five Lords Justices of the Peace. ${ }^{26}$

My lords of the Holy Office. I, your unnamed informant, being a Christian and your most loyal servant, do not wish to conceal from you the wicked ways pursued by Giorgio, known as Moreto, mariner, who shows no respect for the holy ordinances you have posted in Santi Giovanni e Paolo, or for the justice of God. For he, in contempt of the holy decrees of mother Church, habitually eats with Jews and associates with them at all times of the year, and he eats and goes masked and makes merry in such a manner as to make no distinction between Lent and Carnival, a thing that is not to be tolerated by your most excellent lordships.

The first point is that on 22 March, at the nuptials of the Jew Solomon Maestro, he [Giorgio], being in attendance with a lighted torch in his hand, invited the Jewish people in and received them in the manner of Jews, and then, when they were assembled, repaired to the house of the Jew Jacob di Oresi, where was the oven at which they cooked capons and other roast meats which are forbidden to us Christians at that season, and he pulled a capon off a spit which they had removed from the oven, and tore it apart and ate it. Present were the said Jacob di Oresi, and Jacob, son of David Bichele, and the man who works pasta for Jacob, and his baker, who are both Christians, whom Jacob will name.

Likewise, concerning the nuptials of Moses Moresco, a Jew, during this same Lent, Tonin, son of the Gobbo [hunchback], warder of the ghetto, had occasion to say to Messer Alvise Minotto, who disposes of a wardership of the ghetto, that this Giorgio eats meat and is worse than a Jew. ${ }^{27}$ When the Jews are holding vigils over new born boys in order to circumcise them he goes along and attends all vigils until daybreak together with the Jews, as is their custom, and when there are feasts and dances he 
attends them and is forever inviting and leading other Christians to them, and he goes masked during Lent. Witnesses are the warders of the ghetto, and Abram Levi, servant to the Jacobi di Mezo, and Benedict, son of Orso Scocho, a Jewish mercer from Padua.

And the said Giorgio is courting a Jewish girl, the daughter of Isaac the Deaf, and because her father the Jew and her relatives and others reproved him and threatened not to give him the girl, it was said that he wanted her at any price, even if he had to think of becoming a Jew. Witnesses are David Medici, and Samson, son of Vital, butcher, his father and uncle to the girl. ${ }^{28}$

On Good Friday he was heard to say in the ghetto that he wanted to scourge himself, and on Easter Saturday when any passer-by touched him he cried: 'Oy, don't touch me, I've been beating myself.' And he said those words in the middle of the house of that Jewish woman that we are building, in the presence of the Jewess Michiela Capagia. Furthermore, by examining the Christian warders and the Jews it will be found that he, Giorgio, is in the ghetto at all hours of the day and night, and this I have made known to your lordships so that, having had the truth, you may give me something to help me live and support my family, and I commend myself to your favour. ${ }^{29}$

\section{Saturday 8th April 1589}

With the noble lords Giovanni Battista Querini and Andrea Bernardo in attendance, and before the reverend master Stefano Guaraldo of Cento, inquisitor, and the reverend lords Anteo Claudo, auditor to the papal nuncio and Desiderio Guidone, vicar to the patriarch, there appeared in answer to a summons Jacob, son of David, a Jew dwelling at present in the Ghetto Vecchio, and the oath was administered to him, which he swore upon a pen, in the manner of the Jews. ${ }^{30}$

Asked if he knew one Giorgio, called Moreto, mariner, how he knew him and for how long, he replied: 'I have known this Giorgio for perhaps six to eight months.'

Asked upon what occasion, he answered: 'This Giorgio frequents the ghetto by day and by night, and it is said that he is courting a young woman, the daughter of Isaac the Deaf.'

Asked how he knew that this man was courting the Jewish girl, he answered: 'I know it because Giorgio has told me on many occasions that he is courting her and that if he could lead her away he would.'

Asked if he had seen Giorgio eating in the ghetto, at what time and on how many occasions, he answered: 'I have seen him do so many times, mostly on the street in the ghetto, and I have seen him eat buns [focaccie] and cottage cheeses [puine], and he snatched the cheeses from the vendors, and it all happened during this Lent just past, but I have not seen him eat meat or capons.'

Asked if he had seen Giorgio at the nuptials which were celebrated in the ghetto, and at other festivals, he answered: 'I have seen him at festivals in the ghetto and seen him dance at those festivals, and this carnival I myself arranged two or three feasts in the house of one of my masters, and Giorgio came there to dance.'

It was said to him: 'With whom did the said Giorgio dance and in what manner?'

He answered: 'He danced with our Jewish women and I have seen the said Giorgio go to dance at all the celebrations in the ghetto, for you cannot hold a ball without he goes to it.'

The witness was asked if he had seen the said Giorgio at the wedding of one Solomon, a Jew, and he answered: 'No, my lord, I did not see him.' 
Duly examined as to personal details, he gave his age as forty years. He confirmed his testimony after it was read over to him and silence was imposed on him upon a penalty to be determined at the court's discretion. ${ }^{31}$

Benedict, aged seventeen, son of Orso dalla Mano, a Jew dwelling in the Ghetto Nuovo. Asked if he knew one Giorgio Moreto, mariner, he answered: 'Yes, my lord.'

Told to say for how long, and on what occasion, he answered: 'Giorgio has frequented the ghetto for perhaps nine years. I have seen him speak with Jews. He used to make a lot of noise, and I have seen him take fruit and eat it.'

Asked if he knew or had heard tell that the said Giorgio has fallen in love in the ghetto, he answered: 'I have heard it said that he is in love with a Jewish girl, the daughter of Isaac the Deaf, a cook.'

Asked if he knew or had seen or heard tell that the said Giorgio had often eaten in the houses of Jews, especially meat or capons, he answered: 'No, my lord, I have not seen him, nor have I heard that said.'

And in response to a question he said: 'I have seen him several times at Jewish festivities, dancing with Jewish women.'

In reply to a question he said: 'I did not see him at the wedding of the Jew Solomon Maestro, because I was not present at that wedding, and I know no more of this matter.'

He confirmed his testimony and added: 'Since you swore me to tell the truth, I have heard from the warders of the ghetto, who are Christians, that this Giorgio sometimes spends the whole night in the ghetto and gives them great trouble in opening and closing it. Their names are Giovanni Maria Razzer and Giacomo Zotto [the lame man], a Friulian, and I do not know the surname of the second man, but he is the son-in-law of Giovanni Maria Razzer.' And he added again: 'I heard this said by certain Jews, who had it from the warders themselves.'

Abraham Levit, son of Vivian, aged twenty-nine, a Jew of the Ghetto Nuovo.

To an apposite question, he replied: 'I have known this Giorgio by sight for seven or eight months and have seen him at a ball disguised in a bautta [a little cloak used in masquerades]. When he came they suspected that it was he, and the maidens withdrew and there was no dancing. It happened during our last Carnival and the Christian Lent. There is a Jewish maiden and it is said that Giorgio is courting her, and that was why they departed.'

To an apposite question he replied: 'I have not seen him eat in the houses of Jews and have heard nothing of such things, but I have certainly seen him eat some of our matzos, which are made of flour and cold water, in the street last Lent. I have heard the warders complain that he lingered in the ghetto until the fourth and fifth hours after sundown.'

Before the same gentlemen there appeared in answer to a summons Alessandro, son of Innocenzo, dwelling in the parish of Santa Maria Formosa, and the oath to tell the truth was administered to him, which he swore on the holy gospels of God.

To an apposite question he answered: 'This year and last I have been to the ghetto to cook their matzos, and at this oven the Jews cook capons, pigeons, veal and several other things, mostly on Friday for Saturday, and in the evening they put the pots in the oven for the sabbath morning.'

Asked if he knew one Giorgio, called the Moreto, mariner, he replied: 'I know one Giorgio, who had himself called by that name throughout the ghetto. He has a 
pointed beard and is taller than me, a young man of some twenty-two or twenty-three years.'

To an apposite question, he said: 'This past Lent, when a couple of Jewish weddings were held in the ghetto (Levantines, I think), after the matzos had been baked they brought capons, doves and tarts to the oven to be cooked, and those who were celebrating the weddings, either the masters or the servants who had brought the stuff to be cooked, said to the Jew who owns the bake house where I was doing the cooking, "Take one of the very best capons for your offering!" So the owner of the bake house took a capon out of the pan, and this Giorgio tore a leg or a wing off this capon which had been cooked, and he ate it, and he smeared some of it on me, and the Jew who owns the bake house, whose name is Gneccole, burst out laughing. I don't remember the exact day, but it was one day last Lent.'

And to an apposite question he said: 'I did not see this Giorgio eat with Jews, but I did see that when the Jews were eating at their celebrations the said Giorgio stood by with a torch in hand to give them light.'

It was said to him: 'Who was present when Giorgio ate the wing or leg of the capon?'

He answered: 'Gneccole and I were present, and so were other Jews, but I do not know them, and when Giorgio held the torch for the Jews the porter who is son of Gobbo and a Christian was also present.'

Duly examined as to personal details, he gave his age as twenty-five years. He confirmed his testimony when it was read over to him.

Antonio, son of Domenico Spadini, aged twenty-four, warder of the ghetto.

In answer to an apposite question he said: 'I know this Giorgio, called the Moreto, mariner, a young man of some twenty-eight years, with a little black beard, of swarthy complexion and my own height, and I have known him since Carnival, for he is forever in the ghetto by day and by night, and gives much trouble in opening and closing the ghetto. And my father remonstrated with him and he swore: "Al cospettazzo de Dio, putanazza de Dio, you are my foe and give me as much displeasure as you can!”32

Asked if he knew or had heard tell or seen that the said Giorgio had eaten meat by day or by night in the ghetto and at what time, he replied: 'Last Lent I saw the said Giorgio eat meat, for there were hens, capons and meat in the Ghetto Nuovo in the house of a banker's servant. The servant is called Moses, his master the banker Samuel, and Moses had taken a wife and was celebrating his wedding, and Giorgio ate on his feet, and eating at the table were the Jews Sosilo, Baruch the tailor, Auromene, Ezekiel, and others who saw when Giorgio ate meat.'

To a question he replied: 'I have seen him many times in the ghetto making a great deal of noise. This Giorgio was in love with a daughter of Isaac the Deaf, and he goes to the festivities in the ghetto, and at night he goes in disguise with a mask on, and he gave me his masks and false beard and cap for safe keeping, and I know nothing more.'

\section{Tuesday 11 April 1589}

Before the illustrious and reverend lord archbishop of Ragusa [Hieronimo Matteucci], papal nuncio, the reverend father inquisitor, and the reverend Don Desiderio Guidone, vicar to the patriarch, with the noble lords Giovanni Battista Querini and Andrea Bernardo in attendance, there appeared in answer to a summons Samson, son of Vital, a Jewish butcher dwelling 
in the Ghetto Vecchio, and the oath to tell the truth was administered to him, which he swore upon a pen, in the manner of the Jews.

Asked if he knew one Giorgio, called the Moreto, mariner, and for how long and upon what occasion, he answered: 'I have known him for about a year, since he arrived on a ship with certain Jews.'

Asked if he knew or had seen or heard that the said Giorgio frequented the ghetto and for what purpose, he replied: "This Giorgio spends almost the entire day in the ghetto and is there at night up to the sixth or seventh hour after sundown, in and out of the usual hours, and hence he stays at a house, because he is courting a Jewish girl, the daughter of Isaac the Deaf.'

Asked if he knew or had heard tell that the said Giorgio had said anything about the said girl, he replied: 'This Giorgio has had occasion to say several times that he wants to lead this girl away, and if he cannot, then to have her he is willing to become a Jew, and I have heard this several times from his own lips. I do not remember who was present at the time. And because I am a butcher in the ghetto this Giorgio has come several times to plague me at my stall and take chops and other meat to eat in company with Jews. To get rid of him I had an order drawn up by an Avogador, but I do not remember who he was, for he did not come to my stall. ${ }^{33}$

In reply to an apposite question, he said: 'These last few days, Giorgio was wounded in the ghetto by certain Christians, on account of the matzos (or so they say) which Giorgio was going round the houses and collecting and was unwilling to give to those young men.'

To a question he said: 'I do not know that this Giorgio ate meat in the ghetto on days forbidden to Christians and I know nothing else of this matter.'

Duly examined as to personal details, he gave his age as forty-three years. He confirmed his testimony when it was read over to him.

Joseph Zozzoli, Jew, son of Salvadio, aged forty-four.

In answer to an apposite question, he said: 'I have known this Giorgio, called Moreto, mariner, for about two years, for he sometimes enters the ghetto and does a little brokering.'

At this point there arrived the noble lord Federico Contarini, procurator of St Mark's.

'I see him almost all the day in the ghetto, for he is courting a Jewish girl, the Deaf Man's daughter.'

He was asked if he knew or had heard tell that the said Giorgio had eaten meat in the ghetto on days forbidden to Christians, and answered: 'I have neither seen nor heard such things.'

He was asked if he knew or had heard anything else concerning the person of the Deaf Man's daughter, and replied: 'I have heard nothing else, save that he is fond of her, and I know nothing more.'

The Jew Benedict the Roman, son of Donato, aged forty-five.

In answer to an apposite question, he said: 'I know one who goes about the ghetto, and his name is Giorgio. I do not know that he is a mariner, but he is known as the Moreto and may be about twenty-five years of age. He has little beard, is not very tall, and seems almost always to be in the ghetto during the day. At night I do not look and have heard nothing; I have no knowledge of his being in love in the ghetto, and I have never seen him eat meat there, for I have no acquaintance with him and do not seek his company.' 
The Jew Abraham, son of Salvadio, aged twenty-six, dwelling in the Ghetto Vecchio.

In answer to an apposite question, he said: 'I have known this Giorgio for some ten to twelve months, and he walks up and down in the ghetto and does some brokering in the ghetto and generally frequents the place; I have seen him around, but have never seen him eat anything save a matzo or two.'

The Jew David Medici, aged twenty-five, dwelling in the Ghetto Vecchio.

In answer to an appropriate question, he said: 'I know this Giorgio, who is a Christian, and I have known him for about a year. He frequents the ghetto and goes to-and-fro all day on the street.'

He was asked if he knew or had heard tell that Giorgio had fallen in love in the ghetto, and answered: 'The crowd in the ghetto say that he is in love and is courting a Jewish girl, the daughter of a deaf Jew called the Steward [Scalco].'

To a question he replied: 'I have never seen him eat or take a meal in the ghetto, nor have I heard of him doing either.'

To a question he replied: 'I never heard tell that Giorgio had occasion to say that if he could not have the Jewish girl he would wish to become a Jew.'

The Jew Jacob, son of Servadio, aged about twenty-eight, dwelling in the Ghetto Vecchio.

To an apposite question he replied: 'I have known this Giorgio for one or two years, and he goes to-and-fro in the ghetto and does a bit of brokering, and I have not heard tell that Giorgio fell in love in the ghetto. I do not know, and I have not seen or heard it said that Giorgio ate in the ghetto by day or by night.'

\section{Thursday 13 April 1589}

With the lord procurator Federico Contarini in attendance, and before the very reverend father, Master Stefano da Cento, inquisitor, the reverend lords Anteo Claudo, auditor of the lord papal nuncio, and Desiderio Guidone, vicar to the patriarch of Venice, the man named below was brought from prison and sworn to tell the truth.

Asked his name, surname, country and occupation, he answered: 'My name is Giorgio Moreto of Venice, and I have had different occupations, for I have been a trader and am now a mariner.'

Asked if he was accustomed to frequent the ghetto and to live there by day and night, and for what reason, he replied: 'It is my habit to frequent the ghetto during the day because I go about and do a bit of brokering, and have sometimes been there at night, when I have gone to celebrations and to eat with Jews and things of that kind.'

To a question he said: 'I have been at many Jewish festivities and do not remember any in particular, but there was one in the house of the Jew Scocco, another in that of Abraham Boaf, and various others which were held at night, and I went to their banquets and ate with them, but never ate any forbidden foods, because they have their feasting at the time of our Lent, and I ate bread, olives and fruits and danced unmasked at their balls upon several occasions, and I danced with the Jewish women, and the Jews ate meat at their meals, but I did not eat at their tables and kept apart, so that even if they were only eating fish I did not have it, but ate only fruit, bread and some of their matzos.'

To a question he said: 'I danced with the Jewish women, both the wives and the maids, and they took me for partner and I them. I have frequented the ghetto ever since I was born, because I live nearby at the Madonna dell' Orto, although I have 
been closely connected with it only for the last sixteen months, of which I spent six or seven in Alexandria, and the rest of the time I have been often in the ghetto.'

He added, in response to another question: 'I would remain in the ghetto until about the fourth, fifth or sixth hour after sundown, but I have never slept there, and if you find out that I did your lordships must do as you please. I could not tell you how many times I ate in the ghetto, but it might have been thirty, forty or a hundred - I do not remember.'

Asked whether he ever ate meat or the products of dairies in that place during Lent, he replied: 'No, my lord, I never did.'

Admonished to tell the truth, he replied: 'I am here to tell the truth, and I trust in God and the Mother of Grace that they will help me to speak it.'

Asked whether he was in love with any Jewish maiden, and if so with whom, he answered: 'I am courting a Jewish maiden, the daughter of those who brought this suit against me, who are not only persecuting me in this place but have pursued me through all the tribunals of Venice. By the grace of God they have never succeeded in harming me, and I do not believe they will do so here.'

To a question he replied: 'Those who brought suit and are persecuting me are the brothers Samuel and Isaac Semchà and their sons and all their relatives; and one Solomon, a Jewish butcher, who is my enemy. Other enemies I do not have, to my knowledge.'

To a question he replied: 'This Jewish girl whom I am courting bears the name of Rachel and I have been wooing her for sixteen months, since I began visiting the ghetto so often.'

Asked if he thought of taking her to wife or had had her in some other way, he answered: 'If the said Rachel had been willing to come with me as she promised, I would have had her baptised and taken her to wife, and I would have done so willingly, and I hope in God that she may still resolve to convert! It is true that I boasted and bragged to many people that I wanted to lead the said Rachel away, but I always meant to do so with her consent, because she promised to come with me, as I said. And because her relatives became aware of this they stopped up the doors and balconies and hatched a thousand plots and wanted to injure me. ${ }^{34}$

Asked whether he had ever had occasion to say or had thought in his heart that if he could not lead this Rachel away he would want her on any terms, even if he thought of becoming a Jew, he answered with a smile: 'I never said or thought or imagined such a thing. I'd have had to be out of my mind!'

On being told that he must resolve to speak the truth, because witnesses have been examined and deposed that he said such things, he answered: 'I never said anything of the sort, and if any false witness has said so, I do not intend to be punished, because it must be some enemy of mine.'

Asked if he had ever blasphemed, by way of intimidating the warders of the ghetto who did not want to open the door for him, he replied: 'No, my lord.'

To a question, he replied: 'The reason for my enmity towards Samson the butcher is that he is the trading partner of Samuel Semchà and that one day I went to ask him for meat and he would not give it to me, and I threatened him, saying that one day I'd get it, for which reason he took out a court order against me at the Avogaria.'

He was told that he must resolve to tell the truth as to whether he ate meat during Lent or at other forbidden times, because there were three witnesses who said that they saw him do so and had not been named by him as enemies, and he answered: 'If 
they say that they saw me eating meat they must be false witnesses, and if one of them was Tonin, son of the Gobbo, a warder in the ghetto, who is a Christian, then I challenge him as a false witness, because he has been declared such by the Criminal Court of the Forty. If another was Benedict Baruc, a Roman Jew, I say the same of him, because he too has been declared a perjurer, and so have one Capon, a Jew, and one Polenta - they are all false witnesses, and have been declared such.'

He was asked if he had other enemies - but he must be truthful - and he replied: 'I have told the truth.'

He was asked if he thought it good, as a Christian, to court Jewish women and seek to lead them astray, and answered: 'Yes, my lord, I do think it good, because I have my conscience, and there have been others who have been led away and been baptised, and so I hope to do with her and have her convert and be baptised, and these things are in my heart and my intentions.'

Asked if there is any Christian baker who is his enemy, he answered: 'I am not aware of having any baker as an enemy.'

In answer to a question, he added: 'Nor any innkeepers, shopkeepers, or others. ${ }^{35}$

Asked if he was ever in a place where meat was cooked, such as capons, roasts, or things of that kind, he answered: 'I was at the bake house of the Jew Jacob di Oresi this last Lent, and I do not know what day it was that, when certain meat was in the oven that the Benini, who are Jews, had had cooked, I took a chicken bone and the whole leg came away, and I said "I too want to eat meat", and I pretended to put it in my mouth but in fact I threw it over my shoulders to a dog, and I did not eat it. If I had eaten it I would tell you, because I would hope for mercy.'

Asked if he would resolve to tell the truth, he replied: 'I have told the truth.' At this point he was returned to his place. He confirmed his testimony when it was read over to him.

\section{Saturday 15th April 1589}

Before the very reverend father inquisitor and the reverend auditor to the papal nuncio and the vicar to the patriarch, with the noble lord Giovanni Battista Querini in attendance, there appeared in answer to a summons the Jew Aaron Macchioro, son of Abraham, dwelling in the Ghetto Vecchio, and swore the oath in the manner of the Jews.

In reply to an apposite question he said: 'I have known this Giorgio Moreto for some fourteen to sixteen months, and I made his acquaintance in the ghetto, and for five or six months he has often been in the place, ever since he returned from Cairo in the Levant. This last Lent in the Christian calendar I went about the ghetto and was on my way home, and when I was in the doorway of Samson the butcher I saw a servant of Solomon Maestro (I could not recall his name) who was preparing the food for the wedding of his son, and this man had a plateful of meat and other things, and I saw Giorgio take a piece of melina stuffed with meat and put it in his mouth and eat it. ${ }^{36}$

He was asked: 'Since it was night-time, how did you see this, and how far were you from him?'

He answered: 'About an arm's length from him, indeed rather less, because it was a narrow place, and I saw him because Giorgio had a lighted torch in hand, since he was going along with the Jews to fetch the stuff from the oven. Because weddings in the ghetto are always held on Wednesdays, this must have been a Wednesday evening according to the Christian calendar with Thursday coming on, and there was nobody 
present but myself and that servant, whose name I do not know, and I have not seen Giorgio eat meat on other occasions.'

Duly examined as to personal details, he gave his age as about twenty years.

With the noble lords Giovanni Battista Querini and Federico Contarini in attendance, the holy tribunal of the Inquisition of Venice, having seen and pondered the record of the present proceedings, have for the time being, for the purpose of avoiding scandal, decreed that the said Giorgio shall be forbidden any further contact with either the Ghetto Vecchio or the Ghetto Nuovo of the Jews, and that on no account shall he venture by day or by night to enter the Ghetto Vecchio or Ghetto Nuovo, nor shall he loiter near their gates, upon pain of being consigned to the galleys to row in chains for a period of three years, and that any person who accuses him of or reports such a transgression shall receive a reward of one hundred lire di piccoli, to be taken from Giorgio's possessions. ${ }^{37}$

\section{Saturday 10 June 1589}

The constable Girolamo Verier [Hieronimus Vitriarius], who serves the Holy Office, reported as follows. 'Yesterday Giacomo Malosso, deputy constable of the Five Lords Justices of the Peace, escorted Giorgio Moreto, mariner, to the prisons of the Holy Office because he had seen and found him in the ghetto on several occasions, even though he has been forbidden to enter the ghetto by a judgment of this Holy Office, on pain of a fine of 100 lire should he disobey. Furthermore, Giorgio, servant to the Holy Office, has seen Giorgio Moreto at the Aseo bridge [near the ghetto] with a Jewish hat upon his head, and the said Giorgio Moreto, now in prison, admitted to me yesterday that he, together with certain butchers, wore a yellow hat upon his head.'

Before the reverend lord papal nuncio, the very reverend father inquisitor and the reverend auditor to the papal nuncio, with the noble lord Giovanni Battista Querini and the procurator Federico Contarini in attendance, there appeared Ser Giorgio, son of Battista of Tarvisio, servant to the Holy Office of the Inquisition in Venice, and the oath to tell the truth was administered to him.

To an apposite question he replied: 'About a month ago, on my way to the parish of the Servites to summon certain witnesses on the orders of this Holy Office, I saw in a little boat [fesolera] that Giorgio who was imprisoned here on the orders of the Holy Office, and with him were three others whom I did not recognise, and Giorgio and the three others all had yellow hats upon their heads, etc.'

Ser Domenico called the Gobbo, warder of the ghetto, aged fifty-six.

To an apposite question, he said upon oath: 'I know Giorgio Moreto, mariner, and on Thursday morning (not yesterday, but last week), when I was in the Ghetto Nuovo selling from my baskets of greenery, he touched my beard and said: "Old man, you'll yet be examined on my account." I said to him: "I rejoice that you are out of trouble!" I never saw him save on that occasion.'

Don Pietro Volpato, son of Don Volpe of Venice, aged thirty-six, broker in the ghetto.

To an apposite question, he replied: 'I know this Giorgio, and he used to be often in the ghetto, and whenever I saw him passing through the Ghetto Vecchio he always said: "I'm going out, I'm going away." I have not seen him since he was imprisoned here at the Holy Office.' 
Ser Pantaleone, son of Don Giuseppe of Venice, aged forty, broker in the ghetto.

To an apposite question he replied: 'I know this Giorgio Moreto, and not yesterday but the other day I saw him pass through the ghetto from the Cannaregio gate to go towards the Ghetto Nuovo.'

Don Albino, son of Francesco, a Grison, aged forty, broker in the ghetto.

On being questioned he said: 'I know this Giorgio Moreto and I saw him last Thursday passing through the ghetto at a run and he was saying: "I'm going away", and he entered from the gate of the Ghetto Nuovo and ran towards the gate of the Ghetto Vecchio, and I saw him only that day.'

The aforesaid Giorgio was brought from prison and arraigned before the said gentlemen and sworn to tell the truth.

Asked if he knew the reason for his arrest, he replied: 'No, my lord, I do not know, because I was taken at the Two Bridges [at Santi Ermagora e Fortunato in Cannaregio] by the officers of the Five Justices of the Peace.'

He was asked: 'Have you in the last few days, since you were released from the prisons of the Holy Office, been in a boat with other men, wearing a Jew's hat upon your head?'

He answered: 'It is more than twenty days since I went to Murano for a joke with two others who are butchers, and one is called Bortolo and the other Giacomo. And for a jest we wore the yellow hats of Jews on the way out and on the way back, and one of those young butchers went to pick the hats up from the ghetto, and I stayed in the boat there at the Beco bridge [at San Giovanni in Bragora, in Castello], and this is two or three cannon-shots away from the ghetto, and we were carrying some carpets which were in the house of one of the butchers, and we bore them to the nunnery of San Matteo [on the island of Mazzorbo], where the man's sister is a nun, and we wore the yellow hats for a joke, not realising that there would be any objection.'

Asked whether this last Thursday he was within the ghetto of the Jews of Venice and if so for what purpose, he answered: 'On Thursday, when I was here at St Mark's, I hailed some young men and we went to a tavern at San Girolamo and ate and drank there, and being tipsy with the wine the young men said: "We want to go down through the ghetto!" I said to them: "Let's go." And so I passed through the ghetto, and I went in by the gate of the Ghetto Nuovo and out through the gates of the Ghetto Vecchio, and with me were Fabio, silk-mercer, and Luca, tailor.'

It was said to him: 'Did you not know that when you were released by the Holy Office a month or two ago you were charged and warned not to enter the ghetto and forbidden even to approach it? You have treated this order with contempt, and have indeed made so bold as to go out in public in a boat, wearing upon your head the yellow hat of a Jew.'

He answered: 'I knew it, I was always aware of it, and to extricate myself from this affair I wanted to join up with the captain of the gunners. This is the first time I have been at fault, I ask for your pardon and mercy, the wine was my undoing.'

At this point the holy tribunal, having seen and heard the aforesaid evidence, ordered the said Giorgio to be sent to row in the galleys of the Venetian state for a spell of three years, in accordance with the decree drawn up on the fifteenth day of April just past, and 100 lire from his possessions shall be given in accordance with the aforesaid decree. ${ }^{38}$ 


\section{Notes}

1 On the historiography of the Inquisition see, for example, G. Henningsen and J. Tedeschi with C. Amiel (eds), The Inquisition in Early Modern Europe: Studies on Sources and Methods (Dekalb, Illinois, 1986); A. Del Col and G. Paolin (eds), L'Inquisizione Romana in Italia nell' età moderna. Archivi, problemi di metodo e nuove ricerche (Rome, 1991).

2 See J. Contreras and G. Henningsen, 'Forty-four thousand cases of the Spanish Inquisition (1540-1700): analysis of a historical data bank', in Henningsen and Tedeschi with Amiel (eds), The Inquisition, pp. 100-29.

3 For proposals see A. Del Col, 'L'inventariazione degli atti processuali dell' Inquisizione Romana', in Del Col and Paolin (eds), L'Inquisizione, pp. 87-116; A. Del Col, 'Strumenti di ricerca per le fonti inquisitoriali in Italia nell' età moderna', Società e storia, 20 (1997), 143-67, 417-24.

4 See C. Ginzburg, The Cheese and the Worms: the Cosmos of a Sixteenth-Century Miller, trans. J. and A. Tedeschi (Baltimore-London, 1980); Cecilia Ferrazzi, Autobiography of an Aspiring Saint, (ed.) and trans. A. J. Schutte (Chicago, 1996).

5 For a useful list of the forty-two tribunals of the Roman Inquisition which were active in the second half of the seventeenth century, see Del Col, 'Strumenti', 153. On the Roman Inquisition in Malta, see F. Ciappara, Society and the Inquisition in Early Modern Malta (San Gwann, Malta, 2001). For the reform of the Roman Inquisition, see for example A. Prosperi, 'Per la storia dell' Inquisizione romana', in Del Col and Paolin (eds), L'Inquisizione, pp. 40-1; A. Prosperi, Tribunali della coscienza. Inquisitori, confessori, missionari (Turin, 1996), pp. 38-40.

6 See P. C. Ioly Zorattini (ed.), Processi del Sant' Uffizio di Venezia contro ebrei e giudaizzanti, 1548-1734 (14 vols, including Appendici and Indici Generali, Florence, 1980-1999). For the Moreto case, see VIII (1587-1598), pp. 81-98. For a brief account of the case, dependent on the manuscript in Archivio di Stato, Venice, Sant' Uffizio, processi, busta 64, see B. Pullan, The Jews of Europe and the Inquisition of Venice, 1550-1670 (Oxford, 1983; reprint, London, 1997), pp. 164-6.

7 See N. S. Davidson, 'The Inquisition in Venice and its documents: some problems of method and analysis', in Del Col and Paolin (eds), L'Inquisizione, pp. 119, 122-4.

8 Prosperi, 'Per la storia', p. 61; Prosperi, Tribunali, pp. 59, 75-8, 87-8.

9 On the composition and operation of the Venetian tribunal, see P. Grendler, The Roman Inquisition and the Venetian Press 1540-1605 (Princeton, 1977), pp. 3949; Pullan, Jews of Europe, pp. 26-44; R. Canosa, Storia dell' Inquisizione in Italia dalla metà del Cinquecento all fine del Settecento (5 vols, Rome, 1986-90), II, pp. 1014, 168-80; A. Del Col, 'Organizzazione, composizione e giurisdizione dei tribunali dell' Inquisizione Romana nella Repubblica di Venezia (1500-1550)', Critica Storica, 25 (1988), 244-94; A. Del Col, 'L'Inquisizione Romana e il potere politico nella Repubblica di Venezia (1540-60)', Critica Storica, 28 (1991), 189-250; Prosperi, Tribunali, pp. 83-103.

10 See J. Martin, 'Per un analisi quantitativa dell' Inquisizione Veneziana', in Del Col and Paolin (eds), L'Inquisizione, p. 151; also Pullan, Jews of Europe, pp. 186-98. Cf. J. Martin, Venice's Hidden Enemies: Italian Heretics in a Renaissance City (Berkeley, Los Angeles and London, 1993), pp. 161-5, 189, 191.

11 For examples see Prosperi, 'L'Inquisizione', p. 52, 58, 61; Prosperi, Tribunali, p. 90. 
12 Del Col, 'Organizzazione', 293-4; Del Col, 'L’Inquisizione', 211-13.

13 Del Col, 'L'Inquisizione', 219.

14 See the records of the trial of Abram Righetto, 29 May 1572, in Ioly Zorattini (ed.), Processi, III (1570-72), p. 128.

15 For all three, see P. Grendler, 'The Tre Savii sopra Eresia 1547-1605: a prosopographical study', Studi Veneziani, new series, 3 (1979), 325-31; for Contarini, G. Cozzi, 'Federico Contarini: un antiquario veneziano tra Rinascimento e Controriforma', Bollettino dell' Istituto di Storia della Società e dello Stato Veneziano, 3 (1961), 190-220, and Grendler, Roman Inquisition, pp. 220-1.

16 For the lay magistracy responsible for convents see the chapter by Mary Laven in this volume. For blasphemy and related offences, see R. Derosas, 'Moralità e giustizia a Venezia nel '500-'600. Gli Esecutori contro la Bestemmia', in G. Cozzi (ed.), Stato, società e giustizia nella Repubblica Veneta (sec. XV-XVIII) (2 vols, Rome, 198085), I, pp. 431-528; G. Cozzi, 'Religione, moralità e giustizia a Venezia: vicende della magistratura degli Esecutori contro la Bestemmia (secoli XVI-XVII)', Ateneo Veneto, new series, 29 (1991), 7-95.

17 For example, by that of the embattled fourteenth-century Catalan inquisitor Eymeric, which had recently been reissued with extensive notes and commentary by the Spanish canonist Francisco Peña: N. Eymeric, Directorium inquisitorum, cum scholiis seu annotationibus eruditissimis D. Francisci Pegnae Hispani, S. Theologiae et Iuris Utriusque Doctoris (Rome, 1578). There were several subsequent editions. See A. Borromeo, 'A proposito del Directorium inquisitorum di Nicolás Eymerich e delle sue edizioni cinquecentesche', Critica storica, 20 (1983), 499-547; J. Tedeschi, 'Inquisitorial sources and their uses', in his The Prosecution of Heresy. Collected Studies on the Inquisition in Early Modern Italy (Binghamton, New York, 1991), pp. 51-5.

18 See G. Cozzi, 'La politica del diritto nella Repubblica di Venezia', in Cozzi (ed.), Stato, società e giustizia, I, pp. 15-152; G. Ruggiero, Violence in Early Renaissance Venice (New Brunswick, New Jersey, 1980), pp. 40-4; G. Ruggiero, The Boundaries of Eros: Sex Crime and Sexuality in Renaissance Venice (New York and Oxford, 1985), pp. 4-5; G. Cozzi, M. Knapton and G. Scarabello, La Repubblica di Venezia nell' età moderna (2 vols, Turin, 1986-1992), I, pp. 113-14, II, pp. 104-5; the texts translated in D. Chambers and B. Pullan (eds), Venice: A Documentary History 14501630 (Oxford, 1992), pp. 102-4.

19 For the Venetian ghetto and the Jewish economy, see B. Pullan, Rich and Poor in Renaissance Venice: The Social Institutions of a Catholic State, to 1620 (Oxford, 1971), pp. 486-8, 538-78; R. Finlay, 'The foundation of the ghetto: Venice, the Jews and the War of the League of Cambrai', Proceedings of the American Philosophical Society, 126 (1982), 140-54; B. Ravid, 'The religious, economic and social background and context of the establishment of the ghetti of Venice', in G. Cozzi (ed.), Gli ebrei e Venezia (secoli XIV-XVIII) (Milan, 1987), pp. 211-59; D. Malkiel, A Separate Republic. The Mechanics and Dynamics of Venetian Jewish Self-Government, 16071624 (Jerusalem, 1991).

20 Cf. Pullan, Jews of Europe, pp. 145-67, 243-74.

21 Pullan, Rich and Poor, pp. 549-51; G. Vercellin, 'Mercanti turchi e sensali a Venezia', Studi Veneziani, new series, 4 (1980), 60-1, 68-9. By about 1674-75 there were twenty-four officially recognised brokers in the ghetto.

22 See B. Ravid, 'Curfew time in the ghetto of Venice', in E. E. Kittell and T. F. Madden (eds), Medieval and Renaissance Venice (Urbana and Chicago, 1999), pp. 251-2. 
23 For this theme see B. Pullan, 'Shakespeare's Shylock: evidence from Venice', in B. Garvin and B. Cooperman (eds), The Jews of Italy: Memory and Identity (Bethesda, Maryland, 2000), pp. 193-208.

24 See Chambers and Pullan (eds), Venice, pp. 122-3, 126-7; on the Mendicanti, Pullan, Rich and Poor, pp. 362-70. For breaches of cloister, see chapter 8 by Mary Laven in this volume.

25 Quoted in S. W. Baron, A Social and Religious History of the Jews (second edition, 18 vols, London, New York and Philadelphia, 1962-80), XIV, pp. 121-2.

26 The Cinque alla Pace were a minor Venetian magistracy responsible for law and order. It is possible that, although this version of the denunciation is clearly addressed to the Inquisition, an earlier version had been submitted to the Cinque alla Pace, who, noting its religious implications, had urged the delator to resubmit it to the Inquisition. Note the remark later made by Giorgio Moreto to the effect that his enemies had 'pursued him through all the tribunals of Venice' and the fact that he was arrested on 9 June by an officer of the Cinque alla Pace, who were evidently still taking an interest in the case.

27 The noble family of Minotto owned at least some of the houses in the ghetto (see Pullan, Jews of Europe, p. 158). The warderships of the ghetto, like many such positions in Venice, were probably paid offices which could be assigned to persons who exercised them through nominated substitutes.

28 The original text differs from the published version and reads: 'Et il dito fa l'amor con una ebrea fiol de Isach dito il Sordo et perché suo padre di esa ebreo et li suoi parenti et altri l'ano represo, li ano manaciati di darli et auto a dir che la vol a tute foze si'l credese a farsi ebreo.' I am grateful to Professor Ioly Zorattini for pointing this out. The wording remains somewhat obscure. There is a note in the margin of the delation: 'He wants a Jewish girl, with whom he is in love, even if he had to think of becoming a Jew'.

29 The informant is not technically an accuser but a delator. He does not personally undertake to prove the case and suffer penalties if he fails to do so. Rather, he hands the case over to the Inquisition, which chooses to investigate it. It would also have been open to the Inquisition to investigate the matter per viam inquisitionis, that is, without a particular delator, but on the strength of reports or rumours, fama or clamor, reaching the judges' ears. See Eymeric, Directorium, pp. 283-4; Peña's notes (separately paginated), pp. 124-6.

30 The practice of swearing an oath on the pen of the court notary was widespread among Italian Jewish communities, and had the same value for Jews as swearing with a sacred object in the hand - see Ioly Zorattini (ed.), Processi, I (1548-1560), p. 157, n.11.

31 For the importance attached to evidence that a suspect had eaten meat or poultry or fat at forbidden times, during Lent or on Fridays and Saturdays without a licence from a parish priest, compare the case of the Venetian mercer Giovanni Zonca in 1582 - see V. Rossato, 'Religione e moralità in un merciaio veneziano del Cinquecento', Studi Veneziani, new series, 13 (1987), 204-5, 208-9, 212-13, 228-31. Itself an offence against ecclesiastical discipline, the violation of Lent aroused suspicion of heretical tendencies.

32 There is a note in the margin, 'Heretical blasphemies'. 'Al cospetto' or 'al cospettazzo de Dio' was a euphemism for 'al dispetto de Dio' or 'in defiance of God' and implicitly denied God's omnipotence; 'putanazza de Dio', a reference to 'God's whore', 
denied the goodness of God. See Pullan, Jews of Europe, pp. 80-2; Canosa, Storia dell' Inquisizione, V, p. 213; Cozzi, 'Religione, moralità e giustizia’, pp. 27-8.

33 The Avogadori di Comun were the attorneys-general or chief law officers of Venice; among much else they acted as examining magistrates and prosecuted in the higher criminal courts.

34 On campaigns for the conversion of Jews to Christianity in Italy, see Pullan, Jews of Europe, pp. 243-312; B. Pullan, 'The conversion of the Jews: the style of Italy', Bulletin of the John Rylands University Library of Manchester, 70 (1988), 53-70, reprinted as Item XI in B. Pullan, Poverty and Charity: Europe, Italy, Venice, 14001700 (Aldershot, 1994).

35 None of the witnesses called had been examined in Giorgio's presence and their names were concealed from him. This was almost universal practice in inquisition cases and was designed to protect witnesses against retaliation. Suspects could of course try to deduce the names of witnesses from the court's questions at their own examination. There were other ways of finding out - some years later a priest under investigation for solicitation in the confessional sent a boy to hang around the door of the Holy Office and see who went in to be interviewed (C. Madricardo, 'Sesso e religione nel Seicento a Venezia: la sollecitazione in confessionale', Studi Veneziani, new series, 16 (1988), 134-5). The prisoner was always asked to name any personal enemies as part of his defence. Should he do so, and give convincing reasons for their enmity, less attention would be paid to their testimony: only evidence of 'mortal enmity', inimicitia capitalis, would disqualify them completely, according to Eymeric's manual - see his Directorium, pp. 295-6.

36 A dish named after the Yiddish melen or the German Mehl, meaning 'flour' - see Ioly Zorattini's note 27 , p. 93, to the text of the trial.

37 The Inquisition had not, apparently, reached any firm conclusions as to Giorgio's guilt. He had admitted attending Jewish festivities, eating unleavened bread and being in the ghetto until all hours of the night, but not eating meat during Lent or sleeping in the ghetto, still less having any serious intention to become a Jew. The evidence against him may have seemed inconclusive. In a more complex case the prisoner might well have been provided with a written document summarising the evidence against him, been provided with an advocate, and even put to the torture with a view to obtaining a full confession on the grounds that the case against him was half-proved but not fully so. However, Eymeric's manual states that in cases concerning the faith one proceeds concisely, simply and smoothly [summarie, simpliciter et de plano] and without the fuss of advocates and judgments ... it is not necessary to offer a written statement [libellum] or to contest the case; groundless appeals are not to be entertained ...' (Eymeric, Directorium, p. 285). The Moreto case shows how that principle could be applied. The Inquisition's first concern was to reform Giorgio's behaviour rather than to punish him - or perhaps they had decided to give him the liberty to convict himself.

38 The Council of Ten had decreed in 1559 that heretics were not to be condemned to the penal galleys for fear that they might disseminate their subversive ideas in all-too-receptive surroundings (Del Col, 'L'Inquisizione', 220). In 1568, however, a rigorous papal nuncio, Facchinetti, had succeeded in getting the law changed so that 'those who deserve it' could now be sent to the galleys (A. Stella, (ed.), Nunziature di Venezia, VIII, Rome, 1963, p. 455). On the penal galleys see A. Viaro, 'La pena della galera: la condizione dei condannati a bordo delle galere veneziane', 
in Cozzi (ed.), Stato, società e giustizia, I, pp. 379-430. In practice a sentence to the galleys was likely to prove far harsher than a sentence of perpetual imprisonment imposed on a more systematic but socially superior offender, who, if he gave evidence of contrition, might be pardoned within a few months, whereas many oarsmen in the penal galleys failed to obtain a prompt release on the expiry of their sentences (see Borromeo, 'A proposito', 542; J. Tedeschi, 'The organisation and procedures of the Roman Inquisition: a sketch', in his The Prosecution, pp. 147-51; the example of the mercer Giovanni Zonca in Rossato, 'Religione', pp. 246-7). 
Brian Pullan - 9781526137463 Downloaded from manchesterhive.com at 04/26/2023 02:58:30PM via free access 